\title{
Downregulation of GJB2 and SLC26A4 Genes Induced by Noise Exposure is Associated with Cochlear Damage
}

\section{Amir Abbasi Garmaroudi}

Tehran University of Medical Sciences

Monireh Khadem

Tehran University of Medical Sciences

Maryam Mirzaei Hotkani

Tehran University of Medical Sciences

Sajjad Mozaffari

Tehran University of Medical Sciences

MohammadReza Monazzam Esmaeilpoor

Tehran University of Medical Sciences

Elham Kazemirad ( $\nabla$ kazemirad@tums.ac.ir)

Tehran University of Medical Sciences https://orcid.org/0000-0001-8634-5584

\section{Research Article}

Keywords: GJB2 \& SLC26A4 genes, Real-time RT-PCR, Hearing impairment, Cochlear tissue, White \& Purple noise

Posted Date: June 29th, 2021

DOl: https://doi.org/10.21203/rs.3.rs-633325/v1

License: (c) (1) This work is licensed under a Creative Commons Attribution 4.0 International License. Read Full License 


\section{Abstract}

Noise can change the pattern of gene expression inducing sensorineural hearing impairment. There is no investigation on effects of noise frequency on the expression of GJB2 and SLC26A4 genes involved in congenital hearing impairment in cochlear tissue. This study investigated impacts of white and purple noise on gene expression and pathologic changes of cochlear tissue. In this study, 32 adult male Westar rats were selected and divided into experimental groups WN (animals exposed to white noise with a frequency range of 100-20000 Hz), PN (animals exposed to purple noise with a frequency range of 4-20 $\mathrm{kHz}$ ) and control groups. All experimental groups were exposed to a sound pressure level of 118-120 dB for 8 hours per day. Cochlear tissue sampling was performed for tissue pathology studies, also RNA was extracted at 1 hour \& 1 week after cessation of noise exposure. The results showed that Both white and purple noises caused permanent damage to the cortical, estrosilica systems of hair cells and ganglion of the hearing nerve. GJB2 and SLC26A4 were downregulated in both groups exposed with white and purple noise. However, differences are notably more significant in 1 weak post-exposure than 1 hour. Our Findings suggest GJB2 and SLC26A4 can be considered as biomarkers of response to noise frequency which is associated with the pathological response of cochlear tissue, leading to sensorineural hearing impairment. It would be suggested the demand for a more conventional approach to assessment of noise-induced hearing loss and subsequently the practice of hearing protection programs.

\section{Introduction}

Noise-induced hearing loss ( $\mathrm{NIHL}$ ) is the most common form of acquired hearing impairment in developed countries and therefore it is considered a public health issue [1]. A wide range of workers is exposed to noise pollution in the workplace, which has been shown to have detrimental effects, such as hearing impairment [2]. Limited studies have been conducted on the effects of high-frequency noises on the expression of genes involved in hearing impairment. One type of noise with a high-frequency range is purple noise and the other which had a range of audible frequencies is white noise. White or octave band noises centered on low frequency and purple noise centered on high frequency [3]. Hearing impairment could be induced by these noises or after exposure to high-intensity noises [4]. studies were demonstrated that exposure to sound pressure level (90-120 dB) and frequency range of $1-7 \mathrm{kHz}$ could induce upregulation of heat shock protein genes [5], Protein $45 \beta$ (GADD45 $\beta$ ), CDK-interacting protein 1 (p21 Cip1) [6], TACII, MHCII, [7] HDAC protein and Connexin 26 [8] in the atrium of inner ear suggesting them as biomarkers of audible frequencies noise response. Moreover, exposure to sound pressure level of $120 \mathrm{~dB}$ and frequency range of $7 \mathrm{kHz}$ resulted in upregulation of $\mathrm{C} 1 \mathrm{~s}$ and Cfi proteins of the Corte system [9]. Stimulation with ultrasonic noises $(16 \mathrm{kHz})$ and $\mathrm{SPL}=130 \mathrm{~dB}$ significantly increased the expression of $\mathrm{CRH}$ (Corticotropin-Releasing Hormone) genes and its CRH-R1 receptor in PVN, also the physical stress caused by these noises had severely affected microglial cells [10]. Moreover, acute exposure to highfrequency noise $(10-20 \mathrm{kHz})$ and $\mathrm{SPL}=110-120 \mathrm{~dB}$ resulted in upregulation of cochlear tissue different proteins such as $\beta$-ACTIN, PRESTIN, and $\beta$-SPECTRIN [11]. Indeed, abnormal noise at different frequencies and times exposure can induce mutation ad changes in the gene expression pattern in 
ganglion and cochlear tissue. In this manner, noise can induce morphological and physiological changes leading to hair-cell death and disorders in different sections of the human auditory system [6, 12-13]. Inner and particularly outer hair cells (IHC and OHC, respectively) especially those located in the basal turn of the cochlea in the auditory system, are very sensitive to noise damage. Thus, the disruption of stereocilia leads to a severe alteration in $\mathrm{HC}$ structural integrity that has been correlated to permanent threshold shifts (PTS) in many species [14-19].

It was documented that several genes are involved in the physiological response of the cochlea to noiseinduced damage. These genes are associated with various biological processes such as oxidative stress and transcriptional signaling $[6,20]$. The gap junction beta-2 (GJB2) gene-encoded one of the most important proteins involved in the regulation of potassium ions in the cochlea, which is located within the spiral cells of the limbus and the spiral ligament fibroblasts [21-22]. The solute carrier 26a4 (SLC26A4) gene consists of the DFNB4 locus, a recessive chromosomal locus, that causes sensorineural hearing impairment in both non-syndromic and syndromic forms (pendred syndrome, PDS) [23]. Studies have shown that pendred syndrome is alike an anion converter whose mutation leads to hearing impairment. Pendred syndrome is most often diagnosed with nerve deafness associated with goiter. Sensorineural hearing impairment due to pendred syndrome is progressive in some cases and causes varying degrees of deafness [23]. Since no research has been performed directly on the effects of white and purple noises exposure on the expression of SLC26A4 and GJB2 genes involved in congenital hearing impairment, in the present study we investigate their expression pattern after exposure with white and purple noise at a different time in the rat. Given that cochlear tissue is the most important sensorineural receptor of sound when exposed to noises, the pathologic changes in this tissue were also investigated.

\section{Materials And Methods}

\section{Study group selection}

In this experimental study, 32 adult male Westar rats were selected and divided into experimental groups $(\mathrm{N}=12) \mathrm{WN}$ (animals exposed to white noise with a frequency range of $100-20000 \mathrm{~Hz}),(\mathrm{N}=12) \mathrm{PN}$ (animals exposed to purple noise with a frequency range of $4-20 \mathrm{kHz}$ ) and the control group $(\mathrm{N}=8)$ (animals exposed to the same environmental conditions but without noise exposure). For each experimental group, 4 rats were selected as the control group (Table 1). Both experimental groups were exposed to a sound pressure level of 118-120 dB for 8 hours per day. 6 rats from the WN exposure group were exposed to white noise for 3 days (WN-3D) and the other 6 rats were exposed to white noise for 6 days (WN-6D). Also, 6 rats from the PN exposure group were exposed to purple noise for 3 days (PN-3D) and the other 6 rats were exposed to purple noise for 6 days (PN-6D). Samples of exposure groups were anesthetized and after biopsy of rat's cochlea, afterward gene expression analysis was performed on them at two-time period 1 hour and 1 week after cessation of noise exposure designated as $1 \mathrm{~h}$ and $1 \mathrm{w}$ for each group (Table 1). Accordingly, to determine the mean normal expression level of GJB2 and $S L C 26 A 4$ genes, control group samples were used under the same environmental conditions but without exposure to the noise. For cochlear tissue pathology studies in experimental groups, 8 rats from the 
exposure groups, 1 hour \& 1 week after cessation of noise exposure ( 2 rats from the WN-3D group, 2 rats from the WN-6D group, 2 rats from the PN-3D group, and 2 rats from the PN-6D group) were considered. Also, for studies of cochlear tissue pathology in a state that was not under any stress or acoustic stimulation, 1 rat was selected from the control group. In this study, the sample size and type of exposures in the tested time-periods, according to the nature of this study, were obtained experimentally and by surveying the results of similar studies in this field of research $[5,8,24]$. The study was done under the principles of the Ethics Research Committee of the School of Public Health, Tehran University of Medical Sciences (Code: IR.TUMS.SPH.REC.1398.220).

Table 1

The summary of groups exposed with white and purple noise in different time

\begin{tabular}{|c|c|c|c|c|}
\hline Groups & $\begin{array}{l}\text { Sample size } \\
(\mathrm{N})\end{array}$ & $\begin{array}{l}\text { Noise } \\
\text { exposure }\end{array}$ & $\begin{array}{l}\text { Time of } \\
\text { exposure } \\
\text { (hour per day) }\end{array}$ & $\begin{array}{l}\text { Time of RNA extraction after } \\
\text { exposure }\end{array}$ \\
\hline $\begin{array}{l}\text { WN-3D- } \\
1 \mathrm{~h}\end{array}$ & 3 & White noise* & 8 hour/ 3D & 1 hour \\
\hline $\begin{array}{l}\text { WN-3D- } \\
1 \mathrm{~W}\end{array}$ & 3 & White noise & 8 hour/ 3D & 1 weak \\
\hline $\begin{array}{l}\text { WN-6D- } \\
1 \mathrm{~h}\end{array}$ & 3 & White noise & 8 hour/ 6D & 1 hour \\
\hline $\begin{array}{l}\text { WN-6D- } \\
1 w\end{array}$ & 3 & White noise & 8 hour/ 6D & 1 weak \\
\hline $\begin{array}{l}\text { PN-3D- } \\
1 \mathrm{~h}\end{array}$ & 3 & $\begin{array}{l}\text { Purple } \\
\text { noise }{ }^{\star \star}\end{array}$ & 8 hour/ 3D & 1 hour \\
\hline $\begin{array}{l}\text { PN-3D- } \\
1 W\end{array}$ & 3 & Purple noise & 8 hour/ 3D & 1 weak \\
\hline $\begin{array}{l}\text { PN-6D- } \\
1 \mathrm{~h}\end{array}$ & 3 & Purple noise & 8 hour/ 6D & 1 hour \\
\hline $\begin{array}{l}\text { PN-6D- } \\
1 W\end{array}$ & 3 & Purple noise & 8 hour/ 6D & 1 weak \\
\hline \multicolumn{5}{|c|}{ *Frequency range: $100-20000 \mathrm{HZ}, \mathrm{SPL}$ (sound pressure level) $=118-120 \mathrm{~dB}$} \\
\hline ** Frequ & range: $4-2$ & SPL (sounc & sure level) $=11$ & $20 \mathrm{~dB}$ \\
\hline
\end{tabular}

\section{Laboratory conditions}

Rats used in this study with a specific weight and age (7-8 weeks, 190-200g) were placed in a highperformance four-cell audio chamber. One week before the start of exposure, they adapted to the conditions of the experimental environment (12 hours of darkness and 12 hours of light, temperature of $25 \pm 2{ }^{\circ} \mathrm{C}$ and humidity of $45-52 \%$ ) and then were exposed to noises at a specific time from 10 am to 6 pm $[5,8]$ and during the period the necessary tests, water, and food were sufficiently provided to the rats. 
Exposure to white and purple noise took place inside a four-cell high-performance audio chamber measuring $60 \times 52 \times 40 \mathrm{~cm}^{3}$. The sound transmission loss from inside the chamber to the outside was 50 decibels. The walls of this chamber are composed of layers of iron sheet, cellulose, air layer, cellulose, iron sheet, and cellulose, respectively. Two holes on the walls of the chamber were used for ventilation of the chamber and to supply enough oxygen for animal samples inside this chamber, a blowing peripheral pump with a flow of 70 liters per minute was used.

\section{Noise exposure}

The noise pollution was generated using computer software (ADOBE AUDITION with version 13.0.7) and distributed inside the chamber by an amplifier (Crown D75A, Elkhart IN) and 2 speakers (RadioShack Corp, Ft Worth TX). Frequency and sound pressure level monitoring were used with SPECTRUM ANALYZER software (version 5.0.2.). Also, to check the uniformity of the sound pressure level in different parts of the chamber, the sound pressure level in different parts was measured by an analytical sound meter (CELL491 catalog model).

\section{Histology tests}

First, the rats were anesthetized by exposure to carbon dioxide in a cubic chamber, then the skull bone was dissected, and the brain of the specimens was removed. The cochlear tissue, which includes the inner ear and is located inside the pterygium, was removed from the tympanic and temporal sections of the auditory system by surgical instruments. The cochlear tissue inside the microtube for extract RNA, as well as histological tests, were performed (tissue fixation, alcohol dehydration, clearing with xylene, impregnation with Paraffin, molding, cutting from the samples with a microtome in thickness of 5 to 10 $\mu \mathrm{m}$ and painting of hematoxylin-eosin). In the end, morphological-pathological examination of cochlear tissue was performed using light microscope images at a 200-micron scale [12, 25].

\section{RNA extraction}

Total RNA was extracted from tissue using Tripure reagent (Roch, Mannheim, Germany) according to the manufacturer's instruction. Briefly, $50 \mathrm{mg}$ of tissue was homogenized and lysed using Tripure reagent. The lysate was mixed with chloroform and vortexed vigorously and then centrifuged at $12,000 \mathrm{~g}$ for 15 min at $4^{\circ} \mathrm{C}$. Afterward, the upper colorless phase was precipitated by adding isopropanol and washed with $75 \%$ ethanol. Finally, RNA was dried at room temperature and dissolved in RNase-free water. The quantity and quality of RNA were evaluated by nanodrop (ND-1000, Thermo Scientific Fisher, Waltham, Massachusetts, USA) and gel electrophoresis, respectively. RNA was treated with DNase to avoid genomic contamination, (Qiagen, Hilden, Germany) according to the manufacturer's instructions.

\section{cDNA synthesis}

Complementary DNA (cDNA) was synthesized using $1 \mu \mathrm{g} \mathrm{RNA}, 2.5 \mu \mathrm{mol} / \mu \mathrm{l}$ oligo-dT (Roche, Mannheim, Germany) and $60 \mu \mathrm{mol} / \mu \mathrm{l}$ random hexamers (Roche, Mannheim, Germany) incubated $10 \mathrm{~min}$ at $65^{\circ} \mathrm{C}$ followed by addition of $10 \mathrm{mM}$ of dNTP mix (Deoxy Nucleoside Triphosphate mix) (Roche, Mannheim, Germany) $40 \mathrm{U} / \mu \mathrm{l}$ RNase inhibitor (Roche, Mannheim, Germany), $4 \mu \mathrm{L}$ of $5 \mathrm{X}$ reverse transcriptase (RT) 
buffer (Roche, Mannheim, Germany) and $20 \mathrm{U} / \mu \mathrm{L}$ reverse transcriptase enzyme (Roche, Mannheim, Germany) and then incubated at $25^{\circ} \mathrm{C}$ for $10 \mathrm{~min}$ followed by incubation at $50^{\circ} \mathrm{C}$ for $60 \mathrm{~min}$. The integrity of cDNA was checked with GAPDH (Glyceraldehyde 3-Phosphate Dehydrogenase) primers (Table 1) as a housekeeping gene. The PCR condition as follows: an initial denaturing step of $94^{\circ} \mathrm{C}$ for 5 min and 35 repetitions of denaturation at $94^{\circ} \mathrm{C}$ for $30 \mathrm{~s}$, annealing at $49^{\circ} \mathrm{C}$ for $30 \mathrm{~s}$, and extension at $72^{\circ} \mathrm{C}$ for $45 \mathrm{~s}$ with a final extension of $72^{\circ} \mathrm{C}$ for $5 \mathrm{~min}$.

\section{Real-time RT-PCR analysis}

To investigate the differences in the RNA expression level of target genes among exposure and control group Real-time reverse transcriptase-PCR (RT-PCR) was used. Specific primers were designed by Primer 3 software version 0.4 .0 (http://www.ncbi.nlm..nih.gov/tools/primer-blast) (Table 2). Two independent RNA preparations were used for each real-time RT PCR experiment. The experiments were performed in $20 \mu \mathrm{l}$ reactions containing $1 \mu \mathrm{l} \mathrm{cDNA}$ target, $100 \mathrm{nM}$ forward and reverse primers, and 1x SYBR® Premix Ex TaqTM II (Takara, Tokyo, Japan). RT-PCR was carried out in duplicate for target genes and GAPDH as a housekeeping gene using a Real-Time System (Applied Biosystems [ABI], Foster City, CA, USA). The PCR condition was as follows: activation at $95^{\circ} \mathrm{C}$ for $3 \mathrm{~min}$, amplification at $95^{\circ} \mathrm{C}$ for $10 \mathrm{~s}, 60^{\circ} \mathrm{C}$ for $32 \mathrm{~s}$ for 40 cycles followed by a melting curve, temperature increments of $0.2^{\circ} \mathrm{C}$ every $30 \mathrm{~s}$ to determine amplification of the expected product [26].

Table 2

Primer sequences of target genes used in real-time RT-PCR

\begin{tabular}{|llll|}
\hline Oligo Name & seq $\mathbf{5}-\mathbf{3}$ & TM \\
\hline \multirow{2}{*}{ GJB2 } & Forward & 5'-TCACTGTCCTCTTCATCTTCCG-3' & 59.51 \\
\cline { 2 - 4 } & Reverse & 5'-CTTCCGTTTCTTTTCGTGTCTC-3' & 57.88 \\
\hline \multirow{2}{*}{ SLC26A4 } & Forward & 5'-CATCATGCCTGGCTGGTTCT-3' & 60.40 \\
\cline { 2 - 4 } & Reverse & 5'-TGGACACCAACATTCCGTCA-3' & 59.53 \\
\hline GAPDH & Forward & 5'-AAGTTCAACGGCACAGTCAAGG-3' & 61.58 \\
\cline { 2 - 4 } & Reverse & 5'-CATACTCAGCACCAGCATCACC-3' & 61.32 \\
\hline
\end{tabular}

\section{Analysis of gene expression}

The expression level of target genes is reported as the gene fold in the noise-exposure samples normalized to the internal control gene (GAPDH) and relative to the control group using the $2^{-\triangle \Delta C T}$ method as previously described [27].

\section{Statistical method}

Statistical calculations were performed by prism Graph pad software with version 9.0.0.121. Relative gene expression value data are mean \pm standard deviation and were normalized to the internal control. The normal distribution hypothesis for quantitative variables was evaluated by the Shapiro-Wilk test and 
$P$-value $<0.05$ was considered statistically significant. Differences among the exposure $\&$ control groups were evaluated by Tukey's Multiple Comparison Test, followed by post hoc pairwise comparisons to determine which differences account for the result of the more inclusive test.

\section{Results}

\section{Chamber sound pressure level measurement reports}

The measurement results showed that the arrangement of sound systems in the chamber was such that the sound pressure level was constant in all parts of the chamber and all samples were in contact with white and purple noise and with increasing distance from the floor surface of the chamber, the sound pressure level has also increased. Also, the SPECTRUM ANALYZER software results showed that the frequency range and produced sounds pressure level in the chamber were quite like the frequency range and target sounds pressure level for the present study.

\section{Results of pathological studies}

Microscopic examination of tissues and their imaging showed that 1 week after cessation of noise exposure, neurons in the samples of groups exposed to white noise (WN-3D and WN-6D) were damaged more seriously than 1 hour after exposure termination (Fig. 1). Also, the nerve cells of the samples exposed to purple noise (PN-3D and PN-6D) were damaged more significantly 1 week after cessation of noise exposure compared to 1 hour after challenge. In the pathologic section, the auditory nerve ganglion and Reisner membrane showed higher structural damage in samples exposed to purple noise (PN-3D and PN-6D) compared to white noise (WN-3D and WN-6D). Besides, 1 week after termination of noise exposure more seriously damaged was detected in samples exposed to purple noise (PN-3D and PN-6D) in comparison with white noise (Fig. 1).

\section{Expression pattern of GJB2 gene}

The results showed that 1 week after cessation of noise exposure, the transcript level of GJB2 was significantly decreased in exposure groups WN-3D, WN-6D, PN-3D, and PN-6D by 0.34-, 0.02-, 0.51- and 0.12 -fold, $p$-value $<0.05$. Also, 1 hour after cessation of noise exposure, the transcript level of GJB2 was significantly decreased in exposure groups WN-3D and WN-6D by 0.51 - and 0.12 -fold, $p$-value $<0.05$, while it was increased in PN-3D (1.26-fold, $p$-value $>0.05$ ) as compared to control. 1 hour after cessation of noise exposure, the PN-6D exposure group was slightly downregulated which was not significantly (0.72fold, $p$-value > 0.05 ). Overall, 1 week after cessation of noise exposure, the average mRNA levels of $G J B 2$ were significantly lower when compared to 1 hour after cessation of noise exposure in all of the exposure groups (Fig. 2).

\section{Expression pattern of SLC26A4 gene}

The results showed that 1 week after termination of noise exposure, the transcript level of SLC26A4 was significantly decreased in exposure groups WN-3D, WN-6D, PN-3D, and PN-6D by 0.31-, 0.009-, 0.43- and 
0.1 -fold, $p$-value $<0.05$. Also, 1 hour after cessation of noise exposure, the transcript level of $S L C 26 A 4$ was significantly decreased in exposure groups WN-3D, WN-6D, and PN-6D by $0.42-, 0.09$ - and 0.28 -fold, $p$ value $<0.05$, while it was slightly increased in PN-3D (1.21-fold, $p$-value $>0.05)$ as compared to control. Additionally, 1 week after cessation of noise exposure, the average expressions of SLC26A4 exhibited more downregulation as compared to 1 hour after cessation of noise exposure in all of the exposure groups (Fig. 3).

\section{Discussion}

The cochlear tissue and hair cells of the Corte system are the most important sensorineural receptors for sound in the human auditory system. Noise exposure could trigger point mutation and alteration in gene expression which resulted in many sensorineural hearing defects [13]. Therefore, it hypothesizes that the cochlear tissue sample can be used as an ideal tissue sample to study the changes of target genes and understanding the mechanisms that induced syndromic/non-syndromic sensorineural hearing impairment. Accordingly, in this study, the effects of two noise types, which had different frequency limits were investigated on the expression of GJB2 and SLC26A4 genes in rate cochlear tissue. One type of noise had a high-frequency range (purple noise) and the other had a range of audible frequencies (white noise). Most studies in the field of gene expression and its relationship with noise have examined only the effects of noises with a certain frequency on the expression of genes [9-10,24,28], while in this study, sound with a different frequency range in the human hearing range $(20-20000 \mathrm{~Hz})$ were analyzed. The results of this study showed that GJB2 and SLC26A4 genes exhibited more downregulation after 6 days exposure of to both white and purple noises in comparison with 3 days exposure, suggested that increasing the duration of time-exposure could induce more alteration in gene expression. Additionally, when compare two-time points of RNA extraction after the termination of noise exposure, it was revealed that the average expression of GJB2 and SLC26A4 genes exhibited more remarkable downregulation 1 week after the termination of noise exposure as compared to 1 hour in all the experiment groups. Inconsistent with the results of gene expression, in pathologic examination of cochlear tissues, it was demonstrated that neurons were damaged more seriously 1 week after cessation of white and purple noise exposure compared to 1 hour after experiments. These results propose that more stable differences in gene expression, as well as more pathologic damage, could be seen in the long-term period after termination of noise exposure.

There is a lack of enough knowledge regarding the expression of GJB2 and SLC26A4 genes after white and purple noise exposure. However, recently several studies have evaluated the expression of some cochlear tissue and hair cells proteins, such as $\beta$-ACTIN, PRESTIN, and $\beta$-SPECTRIN after contact with sound pressure level between $110-120 \mathrm{~dB}$, and the results demonstrated that gene expression was significantly increased in exposure groups $[5,9,11,24]$. Furthermore, it was documented that after exposure of rats with white noise $(4 \mathrm{kHz})$ for 2 days the expression of connexin 26 (CX26) protein in the dorsal wall of the cochlear tissue increased significantly and the amount of protein in ligament fibrocytes was increased [28]. 
In this context, a similar study showed that the expression of heat shock proteins (HSP 27, 70) increased after 1 hour of noise exposure $(100 \mathrm{~dB})$, and the level of the hearing threshold was raised following 4 hours of exposure with the noises, suggesting that changes in HSP gene expression could lead to rapid physiological changes at the level of the auditory threshold [29]. Inconsistent with the former studies, Gratton et al. [6] stated that a sound pressure level of $105 \mathrm{~dB}$ (for 1 hour per day) induces overexpression of HSP70, HSP40, Protein 45 (GADD45 $\beta$ ), and CDK-interacting protein 1 (p21Cip1) genes in cochlear tissue of mouse. However, the discrepancy between the results of these studies and the present study may be due to the difference in time exposure, type of noise, and false-positive and negative results of the real-time reverse transcriptase-PCR technique. Also, 1 hour after cessation of exposure, the expression of both GJB2 and SLC26A4 genes in one group exposed to purple noise (PN-3D) up-regulated and the other groups exposed to white and purple noise down-regulated significantly. These results are inconsistent with a study by Alagramam et. al., [2] in which two groups of mice were exposed to noise with sound pressure levels of 110 and $116 \mathrm{~dB}$ for 1 hour per day. The results showed that exposure to $110 \mathrm{~dB}$ reduced the expression of 221 genes and increased the expression of 55 genes in the cochlea tissue, while after exposure to $116 \mathrm{~dB}$, the expression of 61 Genes was decreased and 243 genes enhanced. Additionally, the expression of Fos Proto-Oncogene in the cochlea increased significantly after exposure to $116 \mathrm{~dB}$, while the expression of calcium-related genes decreased significantly after exposure to $110 \mathrm{~dB}$ suggesting mitogen-activated protein kinase (MAPK) signaling was the major pathway in both levels of noise exposure.

It was demonstrated that acute and chronic noise exposure could change gene expression differently. In agreement with this notion, a study by Eraslan et al. [30] revealed that after acute noise exposure the expression of both $\mathrm{CRH}-\mathrm{R} 1$ and $\mathrm{CRH}-\mathrm{R} 2$ (corticotropin-releasing hormone receptor) genes were downregulated, while after chronic noise-exposure the expression of $\mathrm{CRH}-\mathrm{R} 1$ and $\mathrm{CRH}-\mathrm{R} 2$ genes increased and decreased, respectively. These results are inconsistent with the results of the effects of purple noise on the expression of GJB2 and SLC26A4 genes in the present study in which the gene expression is lower after 6-day exposure compared to 3-day exposure. The results of this study are also in harmony with the findings of a similar study [7] that have shown a significant relationship between changes in gene expression pattern and the incidence of sensorineural hearing impairment. Furthermore, it was documented that GJB2, SOD2, and CAT genes may be involved interactively or independently in the development of NIHL [31]. Moreover, exposure of mice to $110 \mathrm{~dB}$ for 8 hours a day for 5 consecutive days decreased the expression of connexin 26 (CX26) in cochlear tissue and lead to impairment of hair cells in the cortical system and trigger the risk of NIHL [8].

Another important result in this study is that exposure to both white and purple noises has adverse effects such as axonal changes of nerve neurons, destruction of cochlear tissue and hair cells on the samples of the auditory system. These injuries have intensified with the increasing of time-exposure, also purple noise due to the high energy has more destructive effects than white noise. Likewise, it was reported that exposure to loud noises can lead to increased production of nitric acid in the spiral ganglion neuron of pregnant women leading to alteration in the gene-expression pattern of ganglion cell and thereby cell death, and development of congenital hearing impairment [32-33]. It is well documented that 
after damage and destruction of the auditory system, restoration, and reconstruction of nerve cells such as hair cells in mammals is not possible and subsequently can cause cell death in the Corte system, the development of sensorineural hearing impairment, and permanent hearing threshold (PTS) changes [13]. In terms of pathology, cochlear injury induced by noise exposure is a multifactorial degradation process that occurs due to inflammation and direct mechanical responses contributing to apoptosis and necrosis [20]. In this line, changes in the neuron cell body's golico kanghogahse after noise exposure have been reported in ear tissue and other tissues such as the heart [34]. Evidence has also shown that changes in the expression level of proteins related to the auditory system noises cause permanent damage to the auditory nerve ganglion and cochlear tissue neuron tissue to lead to non-syndromic hearing loss or sensorineural syndrome $[8,13,25]$. Given that both white and purple noises have a significant effect on the expression of genes involved in sensorineural hearing impairment (GJB2 and SLC26A4), therefore, research on this issue should be concerned. The discovery of genes that are affected by noises and cause sensorineural hearing impairment can be useful in pathophysiological studies and the development of an appropriate solution for prevention [35].

\section{Conclusion}

Our findings suggest that $G J B 2$ and $S L C 26 A 4$ genes can be considered as biomarkers of response to noise. Also, the pathological results show sensorineural hearing impairment and structural and cellular changes in cochlear tissue following noise exposure. To prevent the effect of noise on genetic changes in the auditory system, appropriate training, and advice should be suggested at the community level, also using engineering or therapeutic control methods could decrease the risk of injury to the hearing system.

\section{Declarations}

\section{Funding}

This research was supported by Tehran University of Medical Sciences \& Health Services, Grant Numbers: 98-3-99-45886.

\section{Conflict of interest /Competing interests}

The authors declare that they have no competing of interest.

\section{Availability of data and materials}

Data will be available on special request to corresponding author.

\section{Authors' contributions}

AAG, MRME and EK collected and analyzed data. AAG and EK wrote the manuscript. MK, MMH and SM reviewed and revised the manuscript. EK and MRME supervised the entire processes. All authors read and approved the final manuscript. 


\section{Ethical approval and consent to participate}

The study was approved by the Ethics Research Committee of the School of Public Health, Tehran University of Medical Sciences (Code: IR.TUMS.SPH.REC.1398.220).

\section{Consent for publication}

All authors read and approved the final manuscript.

\section{References}

1. Sliwinska-Kowalska, M., and Davis, A (2012) Noise-induced hearing loss. Noise and Health. 14(61): 274-280. doi: 10.4103/1463-1741.104893

2. Alagramam KN, Stepanyan R, Jamesdaniel S, Chen DH-C, Davis RR (2014) Noise exposure immediately activates cochlear mitogen-activated protein kinase signaling. Noise \& health. 16(73):400. doi: $10.4103 / 1463-1741.144418$

3. Park, S. N., Back, S. A., Park, K. H., Seo, J. H., Noh, H. I., Akil, O., et al (2013) Comparison of functional and morphologic characteristics of mice models of noise-induced hearing loss. Auris Nasus Larynx. 40(1): 11-17. doi: 10.1016/j.anl. 2011.11.008

4. Kirchner, D. B., Evenson, E., Dobie, R. A., Rabinowitz, P., Crawford, J., Kopke, R., et al (2012) Occupational noise-induced hearing loss: ACOEM task force on occupational hearing loss. J. Occup. Environ. Med. 54(1):106-108. doi: 10. 1097/JOM.0b013e318242677d

5. Ninomiya H, Ohgami N, Oshino R, Kato M, Ohgami K, Li X, et al (2018) Increased expression level of Hsp70 in the inner ears of mice by exposure to low frequency noise. Hearing research. 36(3):49-54. doi: 10.1016/j.heares.2018.02.006

6. Gratton MA, Eleftheriadou A, Garcia J, Verduzco E, Martin GK, Lonsbury-Martin BL, et al (2011) Noiseinduced changes in gene expression in the cochleae of mice differing in their susceptibility to noise damage. Hearing research. 277(1-2):211-26. doi: 10.1016/j.heares.2010.12.014

7. Yang W, Vethanayagam RR, Dong Y, Cai Q, Hu BH (2015) Activation of the antigen presentation function of mononuclear phagocyte populations associated with the basilar membrane of the cochlea after acoustic overstimulation. Neuroscience. 30(3):1-15. doi: 10.1016/j.neuroscience.2015.05.081

8. Zhou X-X, Chen S, Xie L, Ji Y-Z, Wu X, Wang W-W, et al (2016) Reduced Connexin26 in the mature cochlea increases susceptibility to noise-induced hearing loss in mice. International journal of molecular sciences. 17(3):301-308. doi: 10.3390/ijms17030301

9. Patel M, Hu Z, Bard J, Jamison J, Cai Q, Hu BH (2013) Transcriptome characterization by RNA-Seq reveals the involvement of the complement components in noise-traumatized rat cochleae. Neuroscience. 
10. Du F, Yin L, Shi M, Cheng H, Xu X, Liu Z, et al (2010) Involvement of microglial cells in infrasonic noise-induced stress via upregulated expression of corticotrophin releasing hormone type 1 receptor. Neuroscience. 167(3):909-19. doi: 10.1016/j.neuroscience.2010.02.060

11. Chen G-D (2006) Prestin gene expression in the rat cochlea following intense noise exposure. Hearing research. 222(1-2):54-61. doi: 10.1016/j.heares.2006.08.011

12. Manikandan S, Srikumar R, Parthasarathy NJ, Devi RS (2005) Protective effect of acorus calamus L INN on free radical scavengers and lipid peroxidation in discrete regions of brain against noise stress exposed rat. Biological and pharmaceutical Bulletin. 28(12):2327-30. doi: 10.1248/bpb.28.2327

13. Han Y, Wang X, Chen J, Sha SH (2015) Noise-induced cochlear F-actin depolymerization is mediated via ROCK 2/p-ERM signaling. Journal of neurochemistry. 133(5):617-28. doi: 10.1111/jnc.13061

14. Chen, G. D., and Fechter, L. D (2003) The relationship between noise-induced hearing loss and hair cell loss in rats. Hear. Res. 177(1-2): 81-90. doi: 10.1016/s03785955(02)00802-x

15. Hamernik, R. P., and Qiu, W (2000) Correlations among evoked potential thresholds, distortion product optoacoustic emissions and hair cell loss following various noise exposures in the chinchilla. Hear. Res. 150(1-2): 245-257. doi: 10. 1016/s0378-5955(00)00204-5

16. Chen, Y. S., Liu, T. C., Cheng, C. H., Yeh, T. H., Lee, S. Y., and Hsu, C. J (2003) Changes of hair cell stereocilia and threshold shift after acoustic trauma in guinea pigs: comparison between inner and outer hair cells. ORL J. Otorhinolaryngol. Relat. Spec. 65(5): 266-274. doi: 10.1159/000075224

17. Hu, B.H., Henderson, D.N., T.M (2006) Extremely rapid induction of outer hair cell apoptosis in the chinchilla cochlea following exposure to impulse noise. Hear. Res. 211(1-2):16-25. doi:

10.1016/j.heares.2005.08.006

18. Bohne, B. A., Harding, G. W., and Lee, S. C (2007) Death pathways in noise damaged outer hair cells. Hear. Res. 223(1-2): 61-70. doi: 10.1016/j.heares.2006.10. 004

19. Harding, G.W., and Bohne, B. A (2009) Relation of focal hair-cell lesions to noise exposure parameters from a4- or a 0.5- kHz octave band of noise. Hear. Res. 254(1-2): 54-63. doi:

10.1016/j.heares.2009.04.011

20. Yang S, Cai Q, Vethanayagam RR, Wang J, Yang W, Hu BH (2016) Immune defense is the primary function associated with the differentially expressed genes in the cochlea following acoustic trauma. Hearing research. 33(3):283-94. doi: 10.1016/j.heares.2015.10.010 
21. Raphael Y, Wang Y, Lee MK (1994) Intercellular contacts between chick stereocilia after acoustic overstimulation .Hearing research. 73(1):85-91. doi: 10.1016/0378-5955(94)90285-2

22. Martins FTA, Ramos PZ, Svidnicki MCCM, Castilho AM, Sartorato EL (2013) Optimization of simultaneous screening of the main mutations involved in non-syndromic deafness using the TaqMan ${ }^{\circledR}$ OpenArray $^{\text {TM }}$ Genotyping Platform. BMC medical genetics. 14(1):112. doi: 1471-2350/14/112

23. Nonose, Renata Watanabe and Lezirovitz, Karina and de Mello Auricchio, Maria Teresa Balester and Batissoco, Ana Carla and Yamamoto, Guilherme Lopes and Mingroni-Netto, Regina C $\{\backslash$ 'e\} Lia (2018) Mutation analysis of SLC26A4 (Pendrin) gene in a Brazilian sample of hearing-impaired subjects. Journal of BMC medical genetics. 19(1):1-10. Bio Med Central

24. Gong T-W, Fairfield DA, Fullarton L, Dolan DF, Altschuler RA, Kohrman DC, et al (2012) Induction of heat shock proteins by hyperthermia and noise overstimulation in Hsf1-/- mice. Journal of the Association for Research in Otolaryngology. 13(1):29-37. doi: 10.1007/s10162-011-0289-9

25. Kommareddi P, Nair T, Kakaraparthi BN, Galano MM, Miller D, Laczkovich I, et al (2015) Hair cell loss, spiral ganglion degeneration, and progressive sensorineural hearing loss in mice with targeted deletion of Slc44a2/Ctl2. Journal of the Association for Research in Otolaryngology. 16(6):695-712. doi: $10.1007 / \mathrm{s} 10162-015-0547-3$

26. Mohebali, M., Kazemirad, E., Hajjaran, H. et al (2019) Gene expression analysis of antimony resistance in Leishmania tropica using quantitative real-time PCR focused on genes involved in trypanothione metabolism and drug transport. Arch Dermatol Res. 311:9-17.

https://doi.org/10.1007/s00403-018-1872-2

27. Livak KJ, Schmittgen TD (2001) Analysis of relative gene expression data using real-time quantitative PCR and the $2^{-\Delta \Delta c t}$ Method. Methods. 25:402-408. doi: 10.1006/meth.2001

28. Hsu W-C, Wang J-D, Hsu C-J, Lee S-Y, Yeh T-H (2004) Expression of connexin 26 in the lateral wall of the rat cochlea after acoustic trauma. Acta oto-laryngologica. 124(4):459-63. doi:

$10.1080 / 00016480310000584$

29. Sun W, Zhang L, Lu J, Yang G, Laundrie E, Salvi R (2008) Noise exposure-induced enhancement of auditory cortex response and changes in gene expression. Neuroscience. 156(2):374-80. doi: 10.1016/j.neuroscience.2008.07.040

30. Eraslan E, Akyazi I, Ergül-Ekiz E, Matur E (2015) Noise stress changes mRNA expressions of corticotropin-releasing hormone, its receptors in amygdala, and anxiety-related behaviors. Noise \& health. 17(76):141. doi: 10.4103/1463-1741.155838

31. Wang SL, Yu LG, Liu RP, Zhu WZ, Gao WM, Xue LP, et al (2014) Gene-gene interaction of GJB2, SOD2, and CAT on occupational noise-induced hearing loss in Chinese Han population. Europe PMC plus. 
32. Sun D, Li X (2000) The effect of noise exposure on the expression of NOSmRNA in the cochlea. Lin chuang er bi yan hou ke za zhi. Journal of clinical otorhinolaryngology. 14(8):373-4. PMID: 12563903

33. Pfenninger K, Maylie-Pfenninger M-F, Friedman L, Simkowitz P (1984) Lectin labeling of sprouting neurons: III. Type-specific glycoconjugates on growth cones of different origin. Developmental biology. 106(1):97-108. doi: 10.1016/0012-1606(84)90066-6

34. Monsefı M, Talaei T (2005) Changes of heart glycoconjugates by noise stress in mouse as an experimental model. Journal of Applied Animal Research. 27(2):121-4. doi: 10.1080/09712119.2005.9706554

35. Estivill X, Fortina P, Surrey S, Rabionet R, Melchionda S, D'Agruma L, et al (1998) Connexin-26 mutations in sporadic and inherited sensorineural deafness. Lancet. 351(8):394-98. doi: 10.1016/S01406736(97)11124-2Get

\section{Figures}
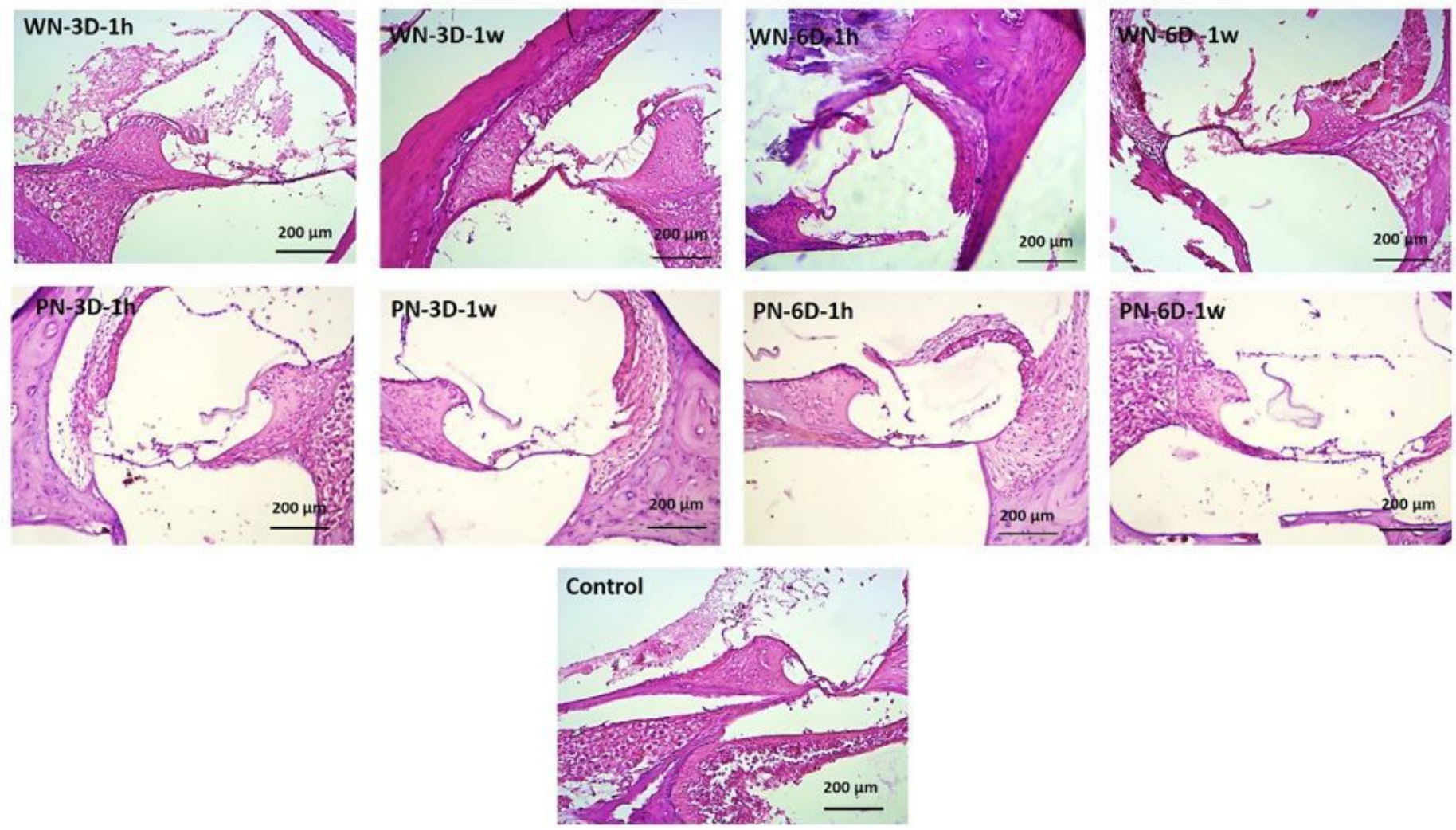

Figure 1 
Tissue image of different exposure group samples, 1 hour and 1 week after cessation of noise exposure. WN-3D, group were exposed to white noise for 3 days; WN-6D, exposed to white noise for 6 days; PN-3D, group were exposed to purple noise for 3 days; PN-6D; exposed to purple noise for 6 days. Pathologic studies in experimental groups 1 hour (1h) \& 1 week (1w) after cessation of noise exposure were conducted

\section{GJB2}

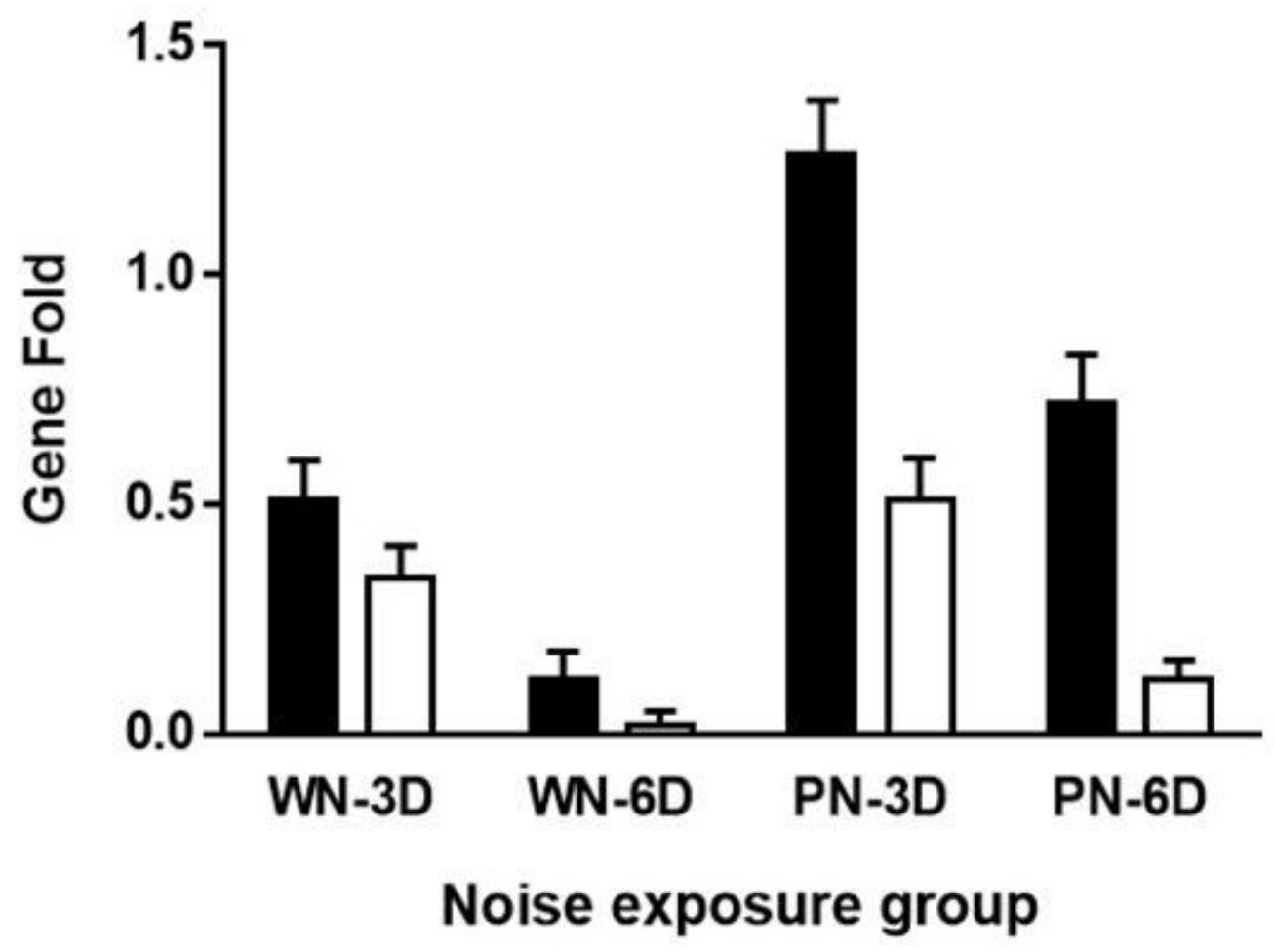

Figure 2

Effect of white \& purple noise on Expression of GJB2 gene. Westar rats were exposed to white \& purple noise (SPL=118-120 dB) for 8hour, and Cochlear RNA was subjected to qRT-PCR for exposure group WN3D, WN-6D, PN-3D, and PN-6D conducted 1 hour (1h) and 1 weak (1w) after cessation of noise exposure. Gene fold change is the ratio of values for noise-exposed rats relative to unexposed controls 


\section{SLC26A4}

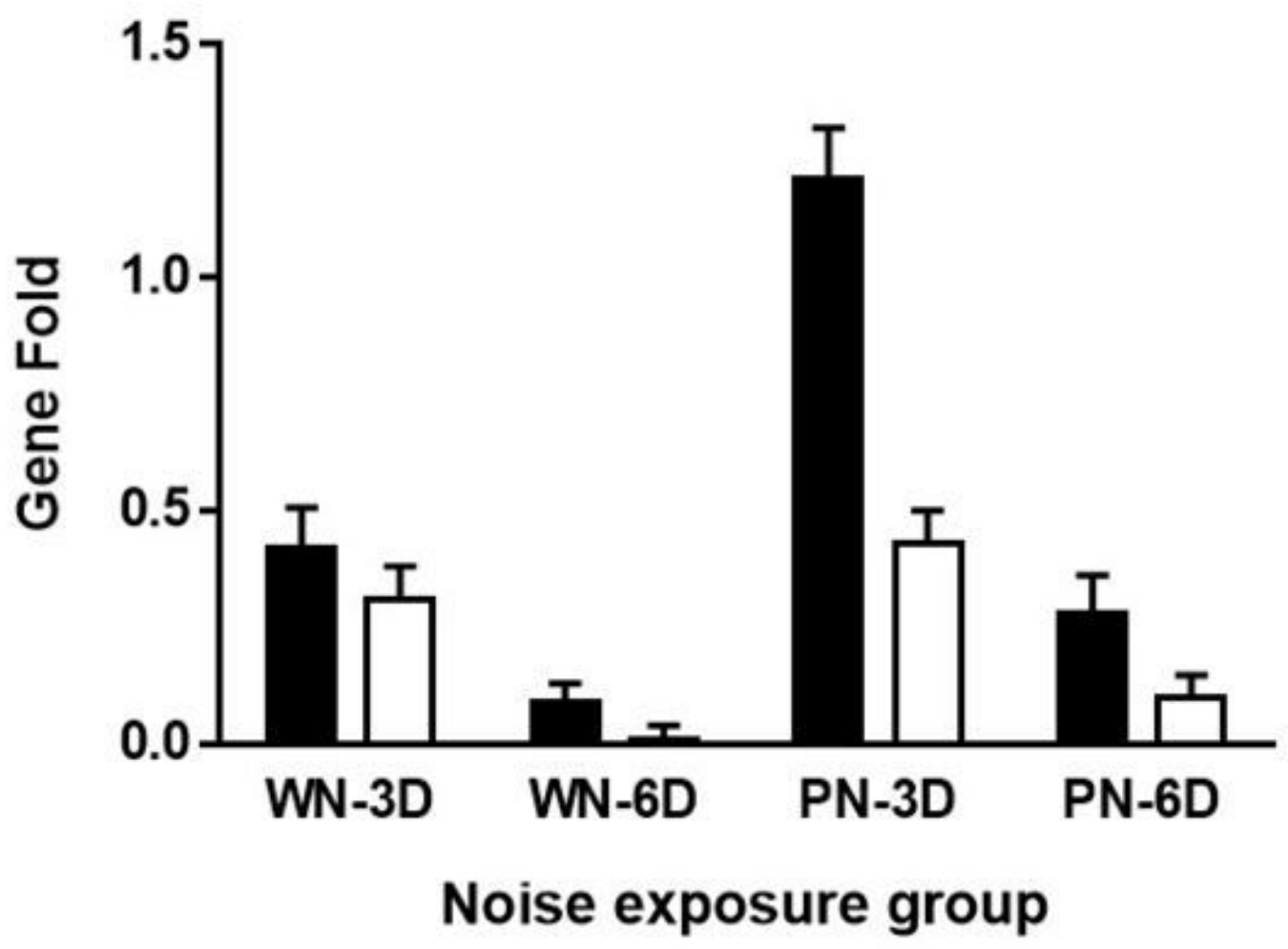

Figure 3

Effect of white \& purple noise on Expression of SLC26A4 gene. Westar rats were exposed to white \& purple noise (SPL=118-120 dB) for 8hour, and Cochlear RNA was subjected to qRT-PCR for exposure group WN-3D, WN-6D, PN-3D, and PN-6D conducted 1 hour (1h) and 1 weak (1w) after cessation of noise exposure. Gene fold change is the ratio of values for noise-exposed rats relative to unexposed controls 